\title{
Research on Dynamic Investment Decision-making of Low-carbon Electric Vehicle under the Uncertain Environment
}

\author{
Wenke Wang 1, 2, a, Jie Gao 3, b, Lin Sun', c, Shuangyu Yang ${ }^{2, ~ d}$, Ying Liü, e \\ ${ }^{1}$ Visual Computing and Virtual Reality Key Laboratory of Sichuan Province, Sichuan Normal \\ University, Chengdu 610068, China \\ ${ }^{2}$ School of business, Sichuan Normal University, Chengdu 610068, China \\ ${ }^{3}$ School of computer science, Sichuan Normal University, Chengdu 610068, China \\ afinance51@126.com, b626688658@qq.com, ‘629341675@qq.com, d550864516@qq.com, \\ eliuliuliuying@hotmail.com
}

\begin{abstract}
Under the development of low-carbon economy, low-carbon electric cars can effectively substitute conventional cars, and help to ease the problems of global energy crisis and environmental pollution. This thesis analyzes the uncertain factors which influence the low-carbon electric cars, and applies the real option theory in combination with the current stages of low-carbon electric vehicle development in our country to set up the Dynamic Investment Decision-making Model based on the Real Option Theory. It also provides modification and supplements for the traditional Net Present Value Method. Through the analysis of numerical calculation, it verifies the operability and scientific validity of the Dynamic Investment Decision-making Model on the low-carbon technology investment decision-making problems of low-carbon electric cars. Finally, we put forward the effective ways to promote the development of low-carbon electric cars in our country.
\end{abstract}

Keywords: The uncertain environment; Low carbon electric vehicle; Low carbon technology; Real option; Dynamic investment.

\section{Introduction}

Accelerating development worldwide of low energy, low pollution, low emission has become the common sense all over the world. Now in each country, the important industry of energy consumption and carbon emission is transportation industry. However, under the background of low-carbon economy, energy-saving, low-emission and the development of new energy of transportation industry will provide guiding roles for the transformation of vehicle industry. This paper considers both risks and uncertainties of technology and market which exist during the low-carbon electric vehicle investment process. At the same time, the dynamic multi-stage decision model has been set up for correctly evaluating low-carbon electric vehicle investment projects with operability in the uncertain environment. While enterprises are able to make best low-carbon investment decisions in most appropriate time by using this model.

\section{Dynamic investment analysis of low-carbon electric vehicle in the uncertain environment}

Technology of low-carbon electric vehicle, including product research and development are relatively complicated. And the process of research and development is link by link with high risks. Because of the development of low-carbon technology stays in an early stage and the state policy making and uncertain environment have impacts on the development of low-carbon electric vehicle. The enterprises need to evaluate the uncertainty of low-carbon electric vehicle market correctly in order to face the uncertain market.

Investments on researching and development of low carbon electric vehicle projects require a lot of capitals and technical support and faces with huge risks. In order to reduce risks, enterprises are supposed to take multi-staged approaches to invest low carbon electric vehicle projects. Real option expands financial option theory which is applied in researching and development, combination and venture capital in both uncertain and high risky environment. The net present value method which 
considers the value of low carbon electric technology investment projects only from a static point of view does not consider insufficient future values with dynamic flexibility. The real option takes opportunity cost of low carbon electric vehicle growth into consideration. Moreover, real option method considers the irreversibility, delayed and flexible value of the low carbon electric vehicle during the investment process. And this means low carbon electric vehicle investments have option rights to make appropriate adjustments according to low carbon investment projects' growth conditions and changeable environment. Hence real option method can fully consider the flexibility for enterprises in investment process and greatly improve the value of low carbon electric vehicle.

\section{Application in low-carbon technological investments based on real option dynamic multi-stage decision model}

\subsection{Assumption of dynamic multi-stage decision model}

Low carbon technology investments can be divided into three parts: they are respectively design period, planning researching and development period and industrial production period of low carbon electric vehicle. And its decision-making process is as figure 1 shows, its parameter and meaning are as table 1 shows:

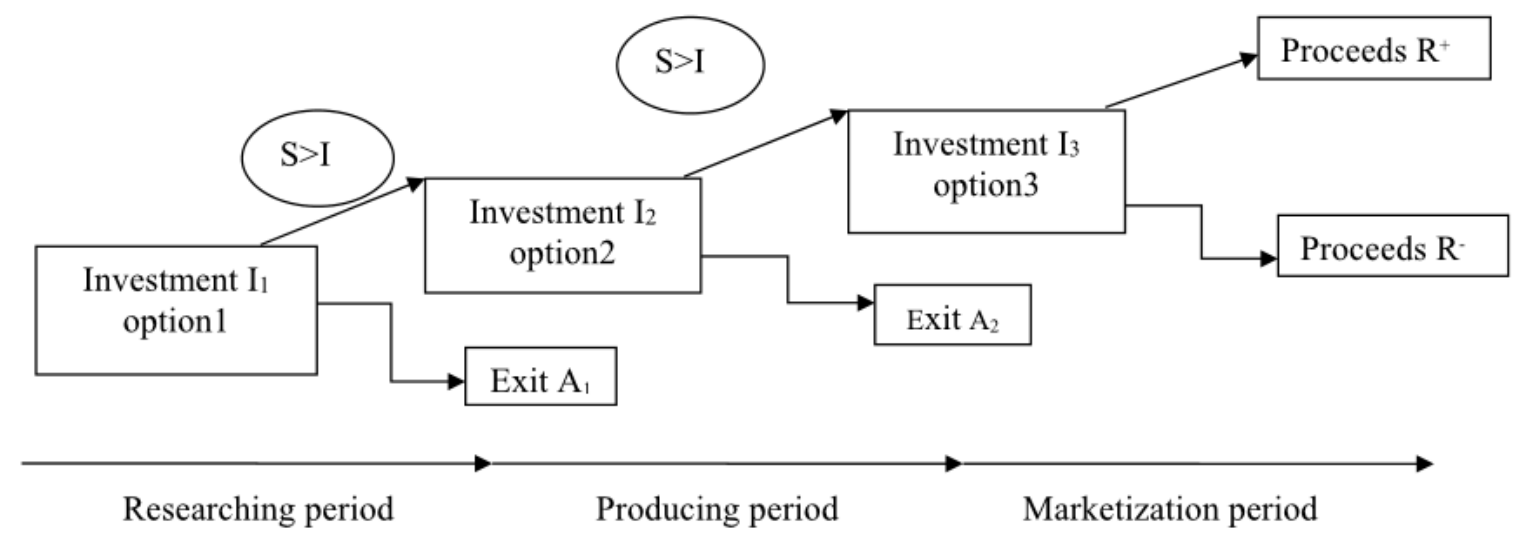

Fig. 1 Low carbon Electric Vehicle investment decision

Table 1 The parameter of the Low carbon Electric Vehicle investment decision-making figure table and meaning,

\begin{tabular}{cc}
\hline Parameter & Explanation \\
\hline $\mathrm{I}_{1}$ & Investment of low carbon electric vehicle during the design period \\
$\mathrm{I}_{2}$ & Investment of low carbon electric vehicle during the research and development period \\
$\mathrm{I}_{3}$ & Investment of low carbon electric vehicle during the industrial production period \\
$\mathrm{t}_{1}$ & Time of low carbon electric vehicle during the design period \\
$\mathrm{t}_{2}$ & Time of low carbon electric vehicle during the research and development period \\
$\mathrm{t}_{3}$ & Time of low carbon electric vehicle during the industrial production period \\
$\mathrm{A}_{1}$ & Proceeds of low carbon electric vehicle during the design period when it failed(existed) \\
$\mathrm{A}_{2}$ & Proceeds of low carbon electric vehicle during the design period when it failed(existed) \\
$\mathrm{R}^{+}$ & Proceeds of low carbon electric vehicle during the design period when it succeed \\
$\mathrm{R}^{-}$ & Proceeds of low carbon electric vehicle during the design period when it succeed
\end{tabular}

Assumptions:

Every stage of investment will lead two results: succeed and fail. If it succeeded, investors implement options and go to next stage of investment. If it failed, investors go into liquidation and get scrap value A. 
Proceeds of low carbon vehicle investment projects have a characteristic of hysteresis, so only in the maturation period can we acquire stable cash flow in assumptions. Assuming $\mathrm{t} 3$ is maturation period, hence we use the market value $\mathrm{R}$ at $\mathrm{t} 3$ instead of subsequent cash flow.

\subsection{Building up dynamic multi-stage binary tree decision model}

Aiming at the characteristic of low-carbon electric vehicle in dynamic multi-stage investment, the description of its investment decision process is as Table 2 follows, and Table 3 shows the parameter and explanation in dynamic multi-stage investment model

Table 2 The parameter list of the call

\begin{tabular}{|c|c|c|c|c|}
\hline \multirow{2}{*}{ Option } & \multicolumn{4}{|c|}{ Parameter } \\
\hline & Underlying assets & Price & Due date & Expense \\
\hline $\begin{array}{c}\text { Option } \\
1\end{array}$ & $\begin{array}{l}\text { Value of Animation-creative } \\
\text { projects after planning and } \\
\text { researching period }\end{array}$ & $\begin{array}{c}\text { Present value of } \\
I_{1}\end{array}$ & $\begin{array}{l}\text { planning, researching } \\
\text { and developing } \\
\text { period }\end{array}$ & $\begin{array}{l}\text { Investments of product } \\
\text { design }\end{array}$ \\
\hline $\begin{array}{c}\text { Option } \\
2\end{array}$ & $\begin{array}{c}\text { Value of animation-creative } \\
\text { projects after product realization } \\
\text { period }\end{array}$ & $\begin{array}{l}\text { Present value of } \\
\qquad I_{2}\end{array}$ & $\begin{array}{l}\text { Industrial product } \\
\text { period }\end{array}$ & $\begin{array}{l}\text { Investments of } \\
\text { planning, researching } \\
\text { and developing }\end{array}$ \\
\hline
\end{tabular}

Note: Present value in the table means present value of each option when they get, for example, the present value of $\mathrm{OP}_{1}$ parameter represents discounting each parameter to the figure in product designing period.

Table 3 Build dynamic multi-stage decision-making model parameters used in table and its significance

\begin{tabular}{|c|c|c|}
\hline \multicolumn{2}{|c|}{ Parameter } & Explanation \\
\hline S1 & S2 & Underlying assets' value of $\mathrm{OP}_{1}$ and $\mathrm{OP}_{2}$ \\
\hline S1+ & S2+ & Value of $\mathrm{OP}_{1}$ and $\mathrm{OP}_{2}$ after increasing \\
\hline $\mathrm{S} 1-$ & S2- & Value of $\mathrm{OP}_{1}$ and $\mathrm{OP}_{2}$ after decreasing \\
\hline E1 & E2 & Value of $\mathrm{OP}_{1}$ and $\mathrm{OP}_{2}$ \\
\hline E1+ & E2+ & Underlying assets' value of $\mathrm{OP}_{1}$ and $\mathrm{OP}_{2}$ when they are increasing \\
\hline E1- & E2- & Underlying assets' value of $\mathrm{OP}_{1}$ and $\mathrm{OP}_{2}$ when they are decreasing \\
\hline P1 & P2 & Underlying assets' increasing neutral risk probability of $\mathrm{OP}_{1}$ and $\mathrm{OP}_{2}$ \\
\hline F1 & F2 & Option expense of $\mathrm{OP}_{1}$ and $\mathrm{OP}_{2}$ \\
\hline OP1 & OP2 & Option premium of $\mathrm{OP}_{1}$ and $\mathrm{OP}_{2}$ \\
\hline & q & Possibility of low carbon electric vehicle investment project gaining vendibility R+ \\
\hline & $\mathrm{k}$ & Risk discount rate in NPV method \\
\hline & r & Risk-free interest rate \\
\hline
\end{tabular}

This low carbon electric vehicle project's market value is constituted by NPV and its flexible value. Hence the real value of low carbon electric vehicle is called extended net present value (ENPV). ENPV shows option premium which is the difference between option value and option expense as well.

Calculate option premium of OP1

Discussion on the carrying out backward inference method in calculating the option premium, firstly we calculate the option premium of $\mathrm{OP}_{2}$. However, on the analogy of this, we can know the option premium of $\mathrm{OP}_{1}$.Finally, and the calculation procedures are as follows:

Calculating the option premium of OP2 


$$
\begin{aligned}
& S_{2}=\frac{R^{+} \times q+R^{-}(1-q)}{(1+k)^{t_{2}+t_{3}}} \\
& S_{2}^{+}=\frac{R^{+}}{(1+k)^{t_{3}}} S_{2}^{-}=\frac{R^{-}}{(1+k)^{t_{3}}} \\
& E_{2}^{+}=\operatorname{Max}\left(A_{2}, S_{2}^{+}-I_{3}\right) \\
& E_{2}^{-}=\operatorname{Max}\left(A_{2}, S_{2}^{-}-I_{3}\right)
\end{aligned}
$$

According to binomial option pricing model, risk-neutral probability and the value of OP2 of animation-creative projects are respectively as follows:

$$
\begin{aligned}
& P_{2}=\frac{(1+r)^{t_{2}} \times S_{2}-S_{2}^{-}}{S_{2}^{+}-S_{2}^{-}} \\
& E_{2}=\frac{P_{2} \times E_{2}^{+}+\left(1-P_{2}\right) \times E_{2}^{-}}{(1+r)^{t_{2}}}
\end{aligned}
$$

As we can learn from Table1, option fee is : $F_{2}=I_{1} \times(1+k)^{t_{1}}+I_{2}$

Refers to $\mathrm{OP}_{2}=E_{2}-F_{2}$, and calculate the value of $\mathrm{OP}_{2}$.

Calculating the value of OP1:

$$
\begin{aligned}
& S_{1}=\frac{R^{+} \times q+R^{-}(1-q)}{(1+k)^{t_{1}+t_{2}+t_{3}}}-\frac{I_{3}}{(1+k)^{t_{1}+t_{2}}}+O P_{2} \\
& S_{1}^{+}=\frac{R^{+}}{(1+k)^{t_{2}+t_{3}}}-\frac{I_{3}}{(1+k)^{t_{2}}}+O P_{2} \\
& S_{1}^{-}=\frac{R^{-}}{(1+k)^{t_{2}+t_{3}}}-\frac{I_{3}}{(1+k)^{t_{2}}}+O P_{2} \\
& E_{1}^{+}=\operatorname{Max}\left(A_{1}, S_{1}^{+}-I_{2}\right) \\
& E_{1}^{-}=\operatorname{Max}\left(A_{1}, S_{1}^{-}-I_{2}\right)
\end{aligned}
$$

According to binomial option pricing model, risk-neutral probability and the value of $\mathrm{OP}_{1}$ of animation-creative projects are respectively as follows:

$$
\begin{aligned}
& P_{1}=\frac{(1+r)^{t_{1}} S_{1}-S_{1}^{-}}{S_{1}^{+}-S_{1}^{-}} \\
& E_{1}=\frac{P_{1} \times E_{1}^{+}+\left(1-P_{1}\right) \times E_{1}^{-}}{(1+r)^{t_{1}}}
\end{aligned}
$$

As we can learn from Table2, the option fee is : $F_{1}=I_{1}$,

Refers to $O P_{1}=E_{1}-F_{1}$, and calculate the value of $O P_{1}$.

Calculate net present value (NPV) and extended net present value (ENPV)

$$
E N P V=N P V+O P_{1}
$$

Figure of ENPV is the real value of this low carbon technology investment project.

Combined with outer uncertain environment, give a feasibility analysis of the low carbon electric vehicle investment project and put forward policy suggestions. 


\section{Case analysis}

A low carbon electric vehicle enterprise wants to invest a project about low carbon electric vehicle under the government's support. This project can be divided into three stages. Its market value can reach $80,000,000$ if the capital of industrial production period withdrew successfully. However, if it failed, the market value of project is merely 8000,000 . In addition, the possibility of success is $20 \%$, and cash flow discount rate is $15 \%$, risk-free rate of interest is $8 \%$. Other variables of low carbon electric vehicle project are as table 4 . Try to evaluate this project.

Table 4 Low carbon electric car investment projects of the variable value table

\begin{tabular}{llccc}
\hline \multirow{2}{*}{ variable } & stages & & & \\
\cline { 2 - 4 } & Product design period & $\begin{array}{c}\text { Planning, researching } \\
\text { and developing period }\end{array}$ & $\begin{array}{c}\text { Industrial } \\
\text { period }\end{array}$ & product \\
\hline $\begin{array}{l}\text { Investment (10k) } \\
\text { Time (year) }\end{array}$ & 300 & 750 & 200 \\
$\begin{array}{l}\text { Liquidation } \\
\text { (10k) }\end{array}$ & 1 & 2 & 1 \\
\hline
\end{tabular}

Firstly, applying net present value method, calculate NPV of this low carbon electric vehicle investment project:

$$
\left.N P V=\frac{8000 \times 20 \%+800 \times 80 \%}{(1+15 \%)^{5}}-\frac{200}{(1+15 \%)^{4}}-\frac{750}{1+15 \%}-300 \approx 47.15 \text { 万元 }\right)
$$

Then calculate the flexible value which is included in low carbon electric vehicle investment projects, according the formula mentioned in the paper, the computational result is as follows:

$$
E N P V=N P V+O P_{1} \approx 541.54
$$

\section{Summary}

The government needs to develop more relevant supporting preferential policies. The government can not only set up a special fund for low carbon electric vehicle technology, but also organize related personnel to research and develop main core technology strongly. And make relevant policies and regulations, give appropriate tax incentives. Combine administrative intervention and related supporting preferential policies to accelerate the development of Chinese low carbon electric vehicle industry.

By applying real option method, this paper built up a dynamic multi-stage binary tree model based on real option theory in uncertain environment. Despite what mentioned before, it also modified and added net present value method. Dynamic multi-stage real option evaluation method evaluates low carbon electric vehicle project correctly and greatly improves the feasibility of project investments. This method that effectively avoids risks and realizes the maximization of enterprise offers investors more options to make investments more directly flexible.

During the process of low carbon electric vehicle technology projects, enterprises have a series of options. It is convenient for investors to make decisions, whether to carry out the next step of investments in accordance with specific situations. This strategy brings the higher flexibility as well as appreciation. At the same time, it impels project manager to fulfill their due diligence on each stage, or the project cannot continue. This is the best way to make agency cost minimum during the process and make shareholders' wealth maximum.

Investors can implement different risk management strategies in the light of different stages. In the meanwhile, it improves the whole value of the project and provides both low carbon electric vehicle project investors and government decision makers with significant theoretical basis and decision-making method for making investments and financing decisions scientifically. 
Supported by the Philosophy and Social Sciences Program of Sichuan Province (No. SC15B071), Supported by the Program of the Visual Computing and Virtual Reality Key Laboratory of Sichuan Province(No.KJ201420), Supported by the Program of the Department of Education of Sichuan Province(No.14SB0022), Supported by the Sichuan provincial innovation and entrepreneurship students Training Program(201410636045, 201510636087).

\section{References}

[1]. Dixit A K. Invest and hysteresis [J].Journal of Economic Perspectives. 1992, 6(1):32-107.

[2]. [USA]Tom Arnold and Timothy Falcon Crack. Option Pricing in the Real World: A Generalized Binomial Model with Applications to Real Options [J]. Working Paper. Louisiana State. University and Indiana University, 2000: 118-125.

[3]. Liu Dexue, Xia Jian, Fan Zhiping. A Real Option Method for Assessing the Value of Venture Capital Project [J].Journal of North-eastern University (Nature Science),2002,23(5):491-494.

[4]. You Daming, Zhang Haiyu. Application of Real Option Theory to the Valuation of Seed Stage Venture Enterprise [J]. Science Technology and Industry,2006,6(11):43-46 